\title{
Spectrofluorometric Assays of Human Collagenase Activity Using Native Collagen and Acetyl-Peptide Substrates
}

\author{
Valon Ejupi, Shpend Dragusha, Tsutomu Kabashima, Qinchang Zhu, Ahmed F. M. El-Mahdy, \\ Sheng Yin, Takayuki Shibata, Masaaki Kai* \\ Faculty of Pharmaceutical Sciences, Graduate School of Biomedical Sciences, Nagasaki University, \\ Nagasaki, Japan \\ Email: ${ }^{*}$ ms-kai@nagasaki-u.ac.jp
}

Received 2 March 2015; accepted 26 March 2015; published 31 March 2015

Copyright (C) 2015 by authors and Scientific Research Publishing Inc.

This work is licensed under the Creative Commons Attribution International License (CC BY).

http://creativecommons.org/licenses/by/4.0/

c) (i) Open Access

\begin{abstract}
A selective, sensitive, and convenient assay for human collagenase is required because of its implication in diseases such as rheumatoid arthritis, osteoarthritis, and tumors. Here, a novel assay for human collagenase activity is described in which enzymatic degradation of native collagen or acetyl peptide is determined by using a fluorogenic reaction for oligopeptides. The oligopeptides are quantified spectrofluorometrically with either 3,4-dihydroxyphenylacetic acid or 1,2-dihydroxybenzen reaction in the presence of sodium periodate and sodium borate $(\mathrm{pH} 7$ - 8). These reactions can selectively convert $N$-terminal Gly-containing oligopeptides and $\boldsymbol{N}$-terminal Ile-containing oligopeptides to fluorescence (FL) compounds, respectively, but not proteins, acetyl peptides or amino acids. Under optimized conditions using $1.65 \mu \mathrm{M}$ collagen IV or $1.5 \mathrm{mM}$ Ac-GPQGIAGQ as substrates, this assay exhibits a proportional relationship between FL intensities and human collagenase-3 (MMP-13) concentrations. It can assay endogenous collagenase activities in several biological samples, such as cultured human cells and cheek tissue.
\end{abstract}

\section{Keywords}

Spectrofluorometric Assay, Human Collagenase, Metalloproteinase, Native Collagen, Acetyl Peptide

\section{Introduction}

Matrix metalloproteinases (MMPs) are a family of zinc-dependent enzymes that degrade major proteins in the "Corresponding author.

How to cite this paper: Ejupi, V., Dragusha, S., Kabashima, T., Zhu, Q.C., El-Mahdy, A.F.M., Yin, S., Shibata, T. and Kai, M. (2015) Spectrofluorometric Assays of Human Collagenase Activity Using Native Collagen and Acetyl-Peptide Substrates. Advances in Enzyme Research, 3, 19-29. http://dx.doi.org/10.4236/aer.2015.31003 
extracellular matrix [1]. Human collagenase is a MMP with the ability to cleave triple-helical native collagens at a single site, resulting in two large fragments that are approximately 1/4 and 3/4 of the initial length [2]. Human collagenase-1 (MMP-1), collagenase-2 (MMP-8), and collagenase-3 (MMP-13) have been well-characterized physiologically [3].

MMP-13 degrades several fibrillary collagens such as I, II, III, IV, IX, and X [4]. Elevated gene expression of this enzyme has been observed in patient tissues having malignancies such as adenocarcinoma, squamous cell carcinoma, and basal cell carcinoma [4]. This enzyme is also involved in the pathogenesis of rheumatoid arthritis because it is significantly elevated in the synovial fluid and serum in such patients [5] [6].

Several assays for human collagenase activity use radioisotope-labeled [7]-[10] or fluorescence (FL)-labeled [11] collagens or peptides as substrates. Additionally, several specific anti-collagenase antibodies have been developed for MMP detection and for screening MMP inhibitors [12]-[14]. Even though these human collagenase assays are facile, either enzyme- or FL-labeled antibodies or substrates are required, thus precluding label-free substrates.

We have developed several inexpensive fluorogenic reactions using non-FL organic reagents for the highly sensitive detection of specific oligopeptides. The FL reagents can selectively label a few peptides because they react only with the $\mathrm{N}$-terminal amino acids. For example, hydroxylamine in the presence of cobalt(II) and borate selectively labels $N$-terminal, Tyr-containing peptides [15]. Other selective FL reagents include glyoxal for $N$ terminal Trp-containing peptides [16], 1,2-dihydroxybenzene(DHB) and borate for $N$-terminal Phe-, Ile-, Leu-, Val-, or Ala-containing peptides [17], DHB and 2-[4-(2-hydroxyethyl)piperazin-1-yl] ethanesulfonic acid buffer at pH 7.5 for $N$-terminal Ser-containing peptides [18], 3,4-dihydroxyphenylacetic acid (DHPAA) for $N$-terminal Gly-containing peptides [19], and 3,4-dihydroxybenzoic acid for $N$-terminal Pro-containing peptides [20]. These reagents could be used to analyze several peptides in complex mixtures such as tissues and enzymatic digests [18] [21]-[24].

Previously [24], we reported sensitive quantification of human collagens by using the fluorogenic reagent, DHPAA for labeling $N$-terminal Gly-containing oligopeptides after enzymatic digestion by bacterial collagenase. Here, we used DHPAA to sensitively detect the activity of human collagenase because the enzyme cleaves collagens into large fragments. The fragments are separated from unreacted collagen substrate by ethanol extraction, and their production is quantitatively determined by the DHPAA-based FL reaction for $N$-terminal Gly-containing peptides. The latter peptides can be generated by continued enzymatic digestion of the fragments with excess bacterial collagenase. We have also examined DHB fluorogenic reaction [17] with $\mathrm{N}$-terminal Ile-containing peptides and an acetyl peptide (Ac-GPQGIAGQ), which was reported to be a substrate [25] for human collagenase. Overall, we describe optimized assay protocols for human collagenase activity using the fluorogenic reagents DHPAA and DHB, and discuss the activity of endogenous collagenase in human cells and tissues.

\section{Materials and Methods}

\subsection{Materials}

Human placental collagens I and IV and bovine nasal septum collagen II were purchased from Sigma-Aldrich (St. Louis, MO, USA). Gly-Pro (GP) was obtained from Wako Pure Chemicals (Osaka, Japan) and dissolved in water. Ac-GPQGIAGQ and Ac-GPQAIAGQ were obtained from Sigma-Aldrich. Recombinant human activated collagenase-3 (MMP-13; 100 $\mu \mathrm{g} / \mathrm{mL}$ solution in $0.05 \mathrm{M}$ Tris- $\mathrm{HCl}$ buffer at $\mathrm{pH} 7.6$ containing $0.2 \mathrm{M} \mathrm{NaCl,} 5.0$ $\mathrm{mM} \mathrm{CaCl}_{2}, 20 \mu \mathrm{M} \mathrm{ZnSO}_{4}, 0.1 \%$ bovine serum albumin and $0.0025 \% \mathrm{NaN}_{3}$ ) was purchased from Chondrex Inc. (Redmond, WA, USA). Clostridium hystolyticum collagenase was purchased from Nacalai Tesque (Kyoto, Japan). DHPAA and DHB were purchased from TCI (Tokyo, Japan). Dulbecco's modified Eagle’s medium (DMEM) was purchased from Wako Pure Chemicals. Fetal bovine serum (FBS) was purchased from Gibco- Invitrogen (Grand Island, NY, USA). PSA (100 units/mL penicillin, $0.1 \mathrm{mg} / \mathrm{mL}$ streptomycin and $0.25 \mu \mathrm{g} / \mathrm{mL}$ amphotericin B) was purchased from Nacalai Tesque. Water was purified with a Milli-Q system WR600 A from Millipore (Molsheim, France). All other chemicals were of analytical or guaranteed-reagent grade, and used without further purification.

\subsection{Preparation of Substrate and Enzyme Solutions}

Human collagen IV and acetyl-peptide substrates were dissolved in water. Human collagen I and bovine colla- 
gen II were dissolved in $0.5 \mathrm{M}$ acetic acid at $37^{\circ} \mathrm{C}$ and then neutralized to pH $6.5-7.5$ using $0.5 \mathrm{M} \mathrm{NaOH}$. These substrate solutions were stored at $4^{\circ} \mathrm{C}$, and used within 1 month. MMP-13 enzyme was stored at $-80^{\circ} \mathrm{C}$ until use. The bacterial collagenase $(100 \mu \mathrm{g} / \mathrm{mL})$ was dissolved in a solution of $125 \mathrm{mM}$ borate buffer ( $\mathrm{pH} 7.5)$ and $10 \mathrm{mM} \mathrm{CaCl}_{2}$, and stored at $-20^{\circ} \mathrm{C}$.

HeLa cells or fibroblast cells from normal human skin were cultured in a $10-\mathrm{cm}$ dish, and allowed to grow to $80 \%$ - 90\% confluence in PSA and DMEM containing $10 \%$ FBS by incubating at $37^{\circ} \mathrm{C}$ in a humidified atmosphere of $5 \% \mathrm{CO}_{2}$ and $95 \%$ air. Cells were removed from the dish with trypsin after the second passage (5 - 6 days). After washing once with phosphate-buffered saline solution (PBS), the cells were stored at $-80^{\circ} \mathrm{C}$ until analysis. The cells $\left(10^{6}-10^{7}\right.$ cells/mL) were lysed by repeated $(3 \times) 10$-min sonications at $4^{\circ} \mathrm{C}$ in a $125 \mathrm{mM}$ borate buffer ( $\mathrm{pH} \mathrm{7.5)} \mathrm{containing} 10 \mathrm{mM} \mathrm{CaCl}_{2}$. The lysate was centrifuged at 12,000 $\mathrm{g}$ for 10 min and the supernatant was separated from the pellet, which was then suspended in $125 \mathrm{mM}$ borate buffer (pH 7.5) containing 10 $\mathrm{mM} \mathrm{CaCl} 2$. The supernatant (cytosol) and the pellet (cell debris) were stored at $-80^{\circ} \mathrm{C}$ and used as enzyme sources. Normal human (30 years old) cheek tissue from buccal mucosa was collected with a cotton swab for 2 $3 \mathrm{~min}$ and suspended in PBS. After washing by centrifugation at $1000 \mathrm{~g}$ for $5 \mathrm{~min}$, the precipitated tissue was suspended in $125 \mathrm{mM}$ borate buffer ( $\mathrm{pH} 7.5$ ) containing $10 \mathrm{mM} \mathrm{CaCl}_{2}$ at $4{ }^{\circ} \mathrm{C}$, and then lysed by repeating (3×) 10 -min sonications. The lysate was centrifuged at $12,000 \mathrm{~g}$ for $10 \mathrm{~min}$ and the supernatant was separated from the pellet. The pellet was suspended in $125 \mathrm{mM}$ borate buffer ( $\mathrm{pH} 7.5$ ) containing $10 \mathrm{mM} \mathrm{CaCl}_{2}$, and the supernatant (cytosol) and pellet (cell debris) were stored at $-80^{\circ} \mathrm{C}$ and used as enzyme sources. Total protein content in the cells and tissue fractions were measured with a Quick-Start Bradford Protein Assay kit (Bio-Rad Laboratories, Hercules, CA, USA).

\subsection{Activation of Endogenous Collagenase in Biological Specimens}

Collagenase in human cells or tissue is generally present in an inactivated form and thus needs to be activated as follows [26]. A 100- $\mu \mathrm{L}$ aliquot of each enzyme source was mixed with $80 \mu \mathrm{L}$ of $125 \mathrm{mM}$ borate buffer ( $\mathrm{pH} 7.5$ ) containing $10 \mathrm{mM} \mathrm{CaCl}_{2}$. Then, a portion $(10 \mu \mathrm{L})$ of $43 \mu \mathrm{M}$ trypsin was added and the solution was incubated at $37^{\circ} \mathrm{C}$ for $10 \mathrm{~min}$. After collagenase activation, a portion $(10 \mu \mathrm{L})$ of $3.0 \mathrm{mg} / \mathrm{mL}$ soybean trypsin inhibitor was added. For MMP-13, this activation was not necessary.

\subsection{Assay Protocol for Collagenase Activity Using Collagen Substrate and DHBA FL-Reagent}

A $25-\mu \mathrm{L}$ aliquot of $740 \mathrm{nM}$ MMP-13, or another enzyme source, was mixed with $75 \mu \mathrm{L}$ of 125 mM borate buffer ( $\mathrm{pH} 7.5$ ) containing $10 \mathrm{mM} \mathrm{CaCl}$; the enzymatic reaction was then initiated by adding $100 \mu \mathrm{L}$ of $3.3 \mu \mathrm{M}$ collagen substrate followed by incubation at $37^{\circ} \mathrm{C}$ for $3 \mathrm{~h}$. For negative controls, the enzymatic reaction was performed either without the collagen substrate or the enzyme source. After the reactions, a portion (200 $\mu \mathrm{L})$ of 99.5\% (w/w) ethanol was successively added and thoroughly mixed. The solution was kept in an ice-water bath $\left(0^{\circ} \mathrm{C}-4^{\circ} \mathrm{C}\right)$ for $20 \mathrm{~min}$, and then centrifuged at $9300 \mathrm{~g}$ at $4^{\circ} \mathrm{C}$ for $10 \mathrm{~min}$. The supernatant $(20 \mu \mathrm{L}) \mathrm{containing}$ large peptide fragments from the collagen substrate was mixed with $130 \mu \mathrm{L}$ of $125 \mathrm{mM}$ borate buffer (pH 7.5) containing $10 \mathrm{mM} \mathrm{CaCl}_{2}$. By adding $50 \mu \mathrm{L}$ of $1.0 \mu \mathrm{M}$ bacterial collagenase, and then the mixture was incubated at $37^{\circ} \mathrm{C}$ for $1 \mathrm{~h}$ to produce abundant $N$-terminal Gly-containing oligopeptides. After that incubation, a $40-\mu \mathrm{L}$ aliquot of the reaction mixture was sequentially mixed with $20 \mu \mathrm{L}$ of $250 \mathrm{mM}$ borate buffer $(\mathrm{pH} 7.5), 20 \mu \mathrm{L}$ of $0.75 \mathrm{mM}$ DHPAA, and $20 \mu \mathrm{L}$ of $1.26 \mathrm{mM} \mathrm{NaIO}_{4}$, and then immediately incubated at $37^{\circ} \mathrm{C}$ for $10 \mathrm{~min}$ for $\mathrm{FL}$ labeling. After the incubation, the final mixture was cooled in an ice water bath to stabilize the FL product. The FL intensity at $465 \mathrm{~nm}$ was measured with a spectrofluorometer (FP-7200, Jasco, Tokyo, Japan) during 375-nm excitation in a 3-mm quartz micro-cell. All measurements for each sample were performed in duplicate.

\subsection{Assay Protocol for Collagenase Activity Using FITC-Collagen Substrate}

A commercially available assay kit containing FITC-labeled bovine collagen I (Chondrex Inc. Redmond, WA, USA) was used for a comparison with the new assay methods. According to the manufacturer's protocol, a portion $(50 \mu \mathrm{L})$ of $740 \mathrm{nM}$ MMP-13 or other enzyme sources was mixed with $150 \mu \mathrm{L}$ of solution B (unknown composition). Enzymatic reaction was initiated by mixing with $200 \mu \mathrm{L}$ of $1.0 \mathrm{mg} / \mathrm{mL}$ FITC-labeled bovine collagen I substrate, followed by incubation at $37^{\circ} \mathrm{C}$ for $3 \mathrm{~h}$. For negative controls, the enzymatic reaction was per- 
formed either without the collagen substrate or the enzyme source. To stop the enzymatic reaction, $10 \mu \mathrm{L}$ of 10 $\mathrm{mM}$ o-phenanthroline and $10 \mu \mathrm{L}$ of $38.5 \mu \mathrm{M}$ elastase were added to every sample, followed by incubation at $37^{\circ} \mathrm{C}$ for $10 \mathrm{~min}$. Finally, a $400-\mu \mathrm{L}$ aliquot of extraction buffer (unknown composition) was mixed well with the reaction solution, which was then centrifuged at $9300 \mathrm{~g}$ for $5 \mathrm{~min}$. The supernatant $(100 \mu \mathrm{L})$ was used for the measurement of FL intensity at $520 \mathrm{~nm}$ with the spectrofluorometer during 490-nm excitation in the 3-mm quartz micro-cell. All measurements were performed for each sample in duplicate.

\subsection{Assay Protocol for Collagenase Activity Using Acetyl-peptide Substrate and DHB FL-Reagent}

A $10-\mu \mathrm{L}$ aliquot of $74 \mathrm{nM}$ MMP-13 or of other enzyme sources was mixed with $27 \mu \mathrm{L}$ of $125 \mathrm{mM}$ borate buffer (pH 7.5) containing $10 \mathrm{mM} \mathrm{CaCl}_{2}$, and the enzymatic reaction was initiated by adding $3 \mu \mathrm{L}$ of $20 \mathrm{mM}$ Ac-GPQGIAGQ substrate, followed by incubation at $37^{\circ} \mathrm{C}$ for $3 \mathrm{~h}$. For negative controls, the enzymatic reaction was performed either without the collagen substrate or the enzyme source. The reaction mixture $(40 \mu \mathrm{L})$ was sequentially mixed with $20 \mu \mathrm{L}$ of $250 \mathrm{mM}$ borate buffer (pH 7.5), $20 \mu \mathrm{L}$ of $2.5 \mathrm{mM} \mathrm{DHB}$, and $20 \mu \mathrm{L}$ of $2.5 \mathrm{mM}$ $\mathrm{NaIO}_{4}$, and immediately heated at $100^{\circ} \mathrm{C}$ for $5 \mathrm{~min}$ for FL labeling. After the reaction, the final mixture was cooled in an ice water bath to stabilize the FL product. The FL intensity at $500 \mathrm{~nm}$ was measured with the spectrofluorometer during 385-nm excitation in the 3-mm quartz micro cell. All measurements for each sample were performed in duplicate.

\section{Results and Discussion}

\subsection{Principle of Collagen Substrate Assay}

Collagens have a unique amino acid sequence with approximately 30\% Gly residues in each molecule, with a repeated -Gly-X-Y sequence in which Pro and Hyp frequently appear at the X or Y positions [27]. The bacterial collagenase cleaves collagens at the $N$-terminal of the Gly residue [28] [29]. Therefore, abundant $N$-terminal Gly-containing oligopeptides are produced from one molecule of collagen [24].

As shown in Scheme 1, human collagenase generally cleaves collagens at only Gly-Leu or Gly-Ile binding sites, thus producing large peptide fragments [2]. Here, we extracted these fragments from unreacted collagen IV substrate by centrifugation with ethanol, and then enzymatically degraded them to abundant $N$-terminal Glycontaining oligopeptides by the bacterial collagenase reaction. Thus we amplified the assay sensitivity for human collagenase activity. Finally, the DHPAA FL-reagent [19] was used to selectively label the $N$-terminal

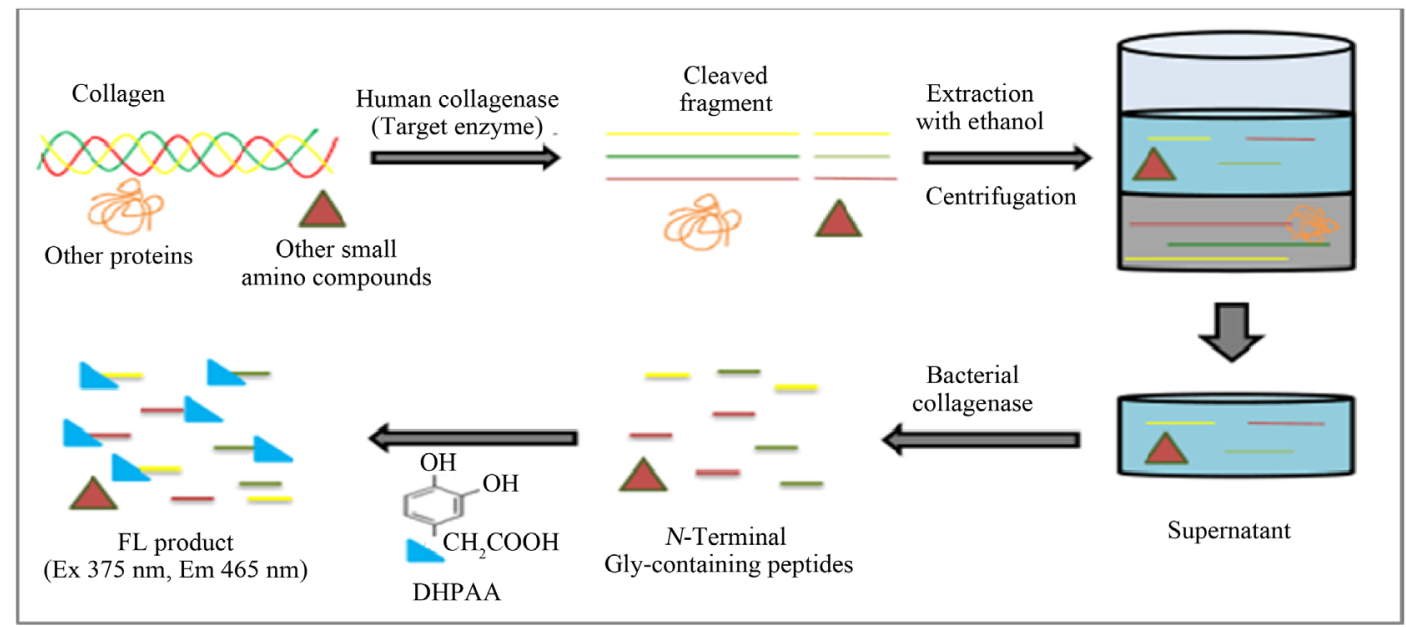

Scheme 1. Protocol for a spectrofluorometric assay of human collagenase activity using collagen substrate. A human collagen IV substrate was hydrolyzed by a small amount of human collagenase (target enzyme) into large fragments. These fragments were then completely degraded by an excess of bacterial collagenase, producing $N$-terminal Gly-containing peptides. The peptides were selectively labeled by a DHPAA-based FL reaction. Relative fluorescence intensity (RFI) was measured at excitation (Ex) and emission (Em) wavelengths of $375 \mathrm{~nm}$ and $465 \mathrm{~nm}$, respectively. 
Gly-containing oligopeptides. This DHPAA-based FL reaction can be performed in a neutral borate solution (pH 7.5) at $37^{\circ} \mathrm{C}$ for $10 \mathrm{~min}$ in the presence of periodate.

\subsection{Assay of MMP-13 Activity}

MMP-13 cleaves triple-helical collagen at Gly-Ileu or Gly-Leu sites, producing large peptide fragments [2]. Here, the affinities of human collagen I, human collagen IV, and bovine collagen II were tested with regard to the MMP-13 enzyme. As shown in Figure 1(a), human collagen IV was more likely to be digested by MMP-13. Thus, the MMP-13 activity assay is based on digestion of the collagen IV substrate.

Because ethanol is a de-proteinization agent, peptide fragments produced by the enzymatic reaction were extracted with ethanol and separated by centrifugation not only from unreacted collagen but also from other endogenous proteins by centrifugation. As shown in Figure 1(b), the background signal from excess substrate was significantly reduced by extraction with 33\% - 50\% ethanol. Therefore, 50\% ethanol was used in enzyme reaction mixtures.

For sensitive detection of human collagenase activity, we tried to produce, via enzymatic reaction with bacterial collagenase, abundant $N$-terminal Gly-containing oligopeptides from the large fragments extracted in the supernatant following MMP-13 collagen digestion. However, 50\% ethanol in the supernatant would inhibit the bacterial collagenase activity. Fortunately, ethanol concentrations $<10 \%$ did not inhibit the bacterial collagenase. Thus, we determined the optimum concentration of bacterial collagenase for the second enzymatic reaction mixture in the presence of 2.5\% ethanol, as shown in Figure 2(a). The results indicated that $250 \mathrm{nM}$ bacterial

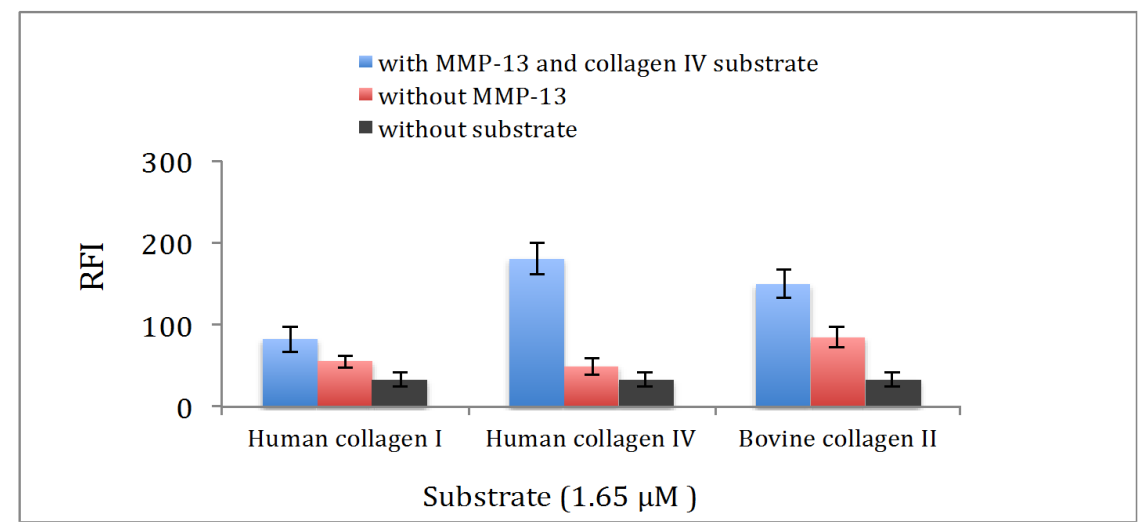

(a)

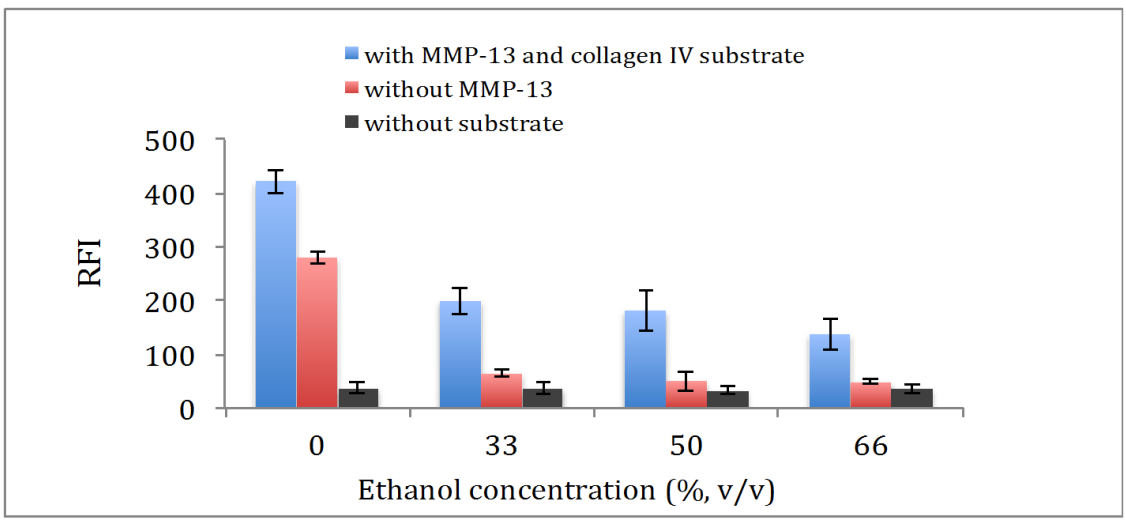

(b)

Figure 1. (a) Degradation of collagen substrates (1.65 $\mu \mathrm{M}$ each) by incubation with MMP-13 enzyme (92.5 nM) at $37^{\circ} \mathrm{C}$ for $3 \mathrm{~h}$; (b) Effect of ethanol concentration as a deproteinization reagent for the extraction of fragments produced from the collagen IV substrate. After the enzymatic reaction, ethanol at a concentration ranging from $0 \%$ to $66 \%$ $(\mathrm{v} / \mathrm{v})$ was added to the mixture, followed by centrifugation. Error bars represent standard deviation in duplicate measurements. 


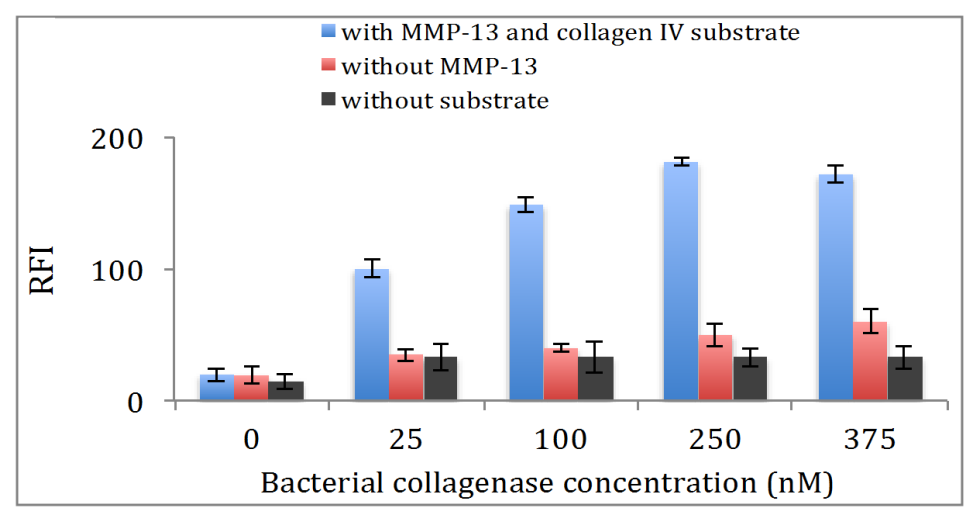

(a)

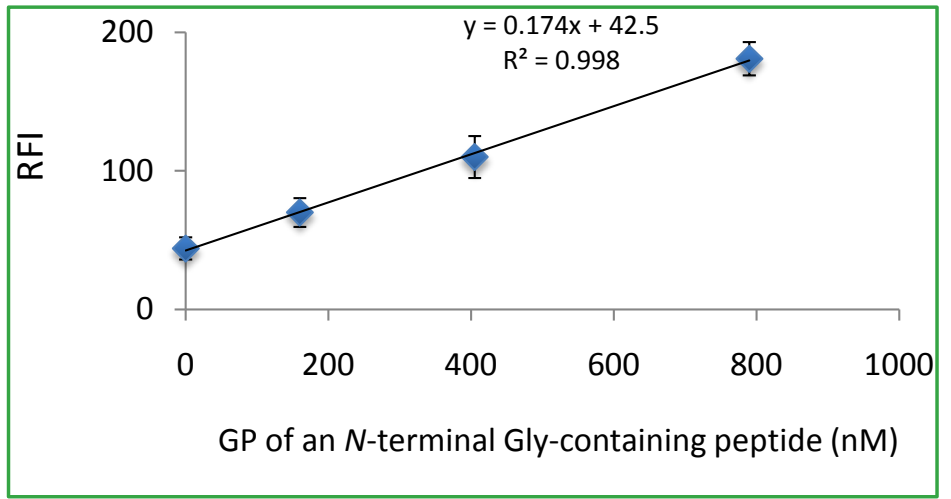

(b)

Figure 2. (a) Effect of bacterial collagenase concentration for production of $\mathrm{N}$-terminal Gly-containing oligopeptides at $37^{\circ} \mathrm{C}$ for $1 \mathrm{~h}$, after the production of large peptide fragments from $1.65 \mu \mathrm{M}$ human collagen IV by $92.5 \mathrm{nM}$ MMP-13 at $37^{\circ} \mathrm{C}$ for $3 \mathrm{~h}$; (b) Calibration curve for GP in the enzymatic reaction mixture, which was determined by FL labeling with $0.15 \mathrm{mM}$ DHPAA at $37^{\circ} \mathrm{C}$ for $10 \mathrm{~min}$ in the presence of $0.25 \mathrm{mM} \mathrm{NaIO}_{4}$ and $50 \mathrm{mM}$ sodium borate (pH7.5). Error bars represent standard deviation in duplicate measurements.

collagenase provided the maximum production of $N$-terminal Gly-containing peptides from the large fragments. Conveniently, this enzymatic reaction can be performed at $37^{\circ} \mathrm{C}$ for $1 \mathrm{~h}$ in the same buffered solution as that used for the human collagenase reaction.

Various concentrations ( 0 - $790 \mathrm{nM}$ ) of an $N$-terminal Gly-containing dipeptide (GP) in the second enzymatic reaction mixture were FL-labeled by the DHPAA reaction in the presence of collagen IV, MMP-13, ethanol, bacterial collagenase, and buffer. As shown in Figure 2(b), the DHPAA yielded FL signals that were proportional to the GP concentrations in the enzymatic reaction mixture

Under conditions described above, $1.65 \mu \mathrm{M}$ human collagen IV was hydrolyzed with $92.5 \mathrm{nM}$ MMP-13 at $37^{\circ} \mathrm{C}$ over a range of incubation times $(0-3 \mathrm{~h})$ and MMP- 13 concentrations $\left(0-185 \mathrm{nM}\right.$, at $37^{\circ} \mathrm{C}$ for $\left.3 \mathrm{~h}\right)$. As shown in Figure 3(a), the enzymatic products from collagen IV digestion increased with incubation time. Therefore the optimal incubation time of $3 \mathrm{~h}$ was determined. Additionally, the FL signals were proportional to enzyme concentrations ranging from 33 - 185 nM, as shown in Figure 3(b). This calibration curve showed a proportional relation $\left(\mathrm{R}^{2}=0.978\right)$ between concentrations of MMP-13 and the FL intensities. The lower limit of detection at 3 of ratio of signal per noise ( $\mathrm{S} / \mathrm{N}=3)$ was $85 \mathrm{nM}$ MMP-13.

\subsection{Comparison with Other Assays}

The collagen IV assay discussed above was used to determine human collagenase activities in several enzyme sources such as HeLa cells $\left(10^{7}\right.$ cells $\left./ \mathrm{mL}\right)$, skin fibroblast cells $\left(10^{6} \mathrm{cell} / \mathrm{mL}\right)$, and cheek tissue from buccal mucosa collected with a cotton swab. As shown in Figure 4(a), we found no significant collagenase activity in the 


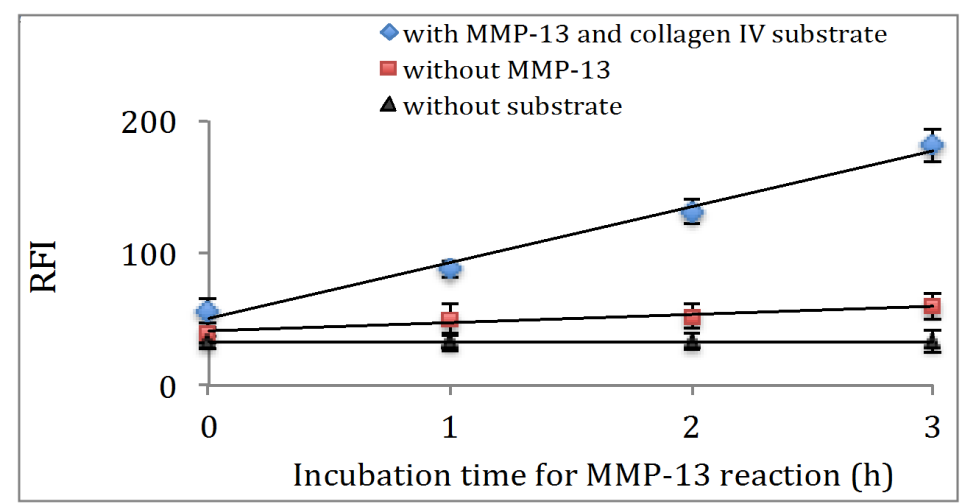

(a)

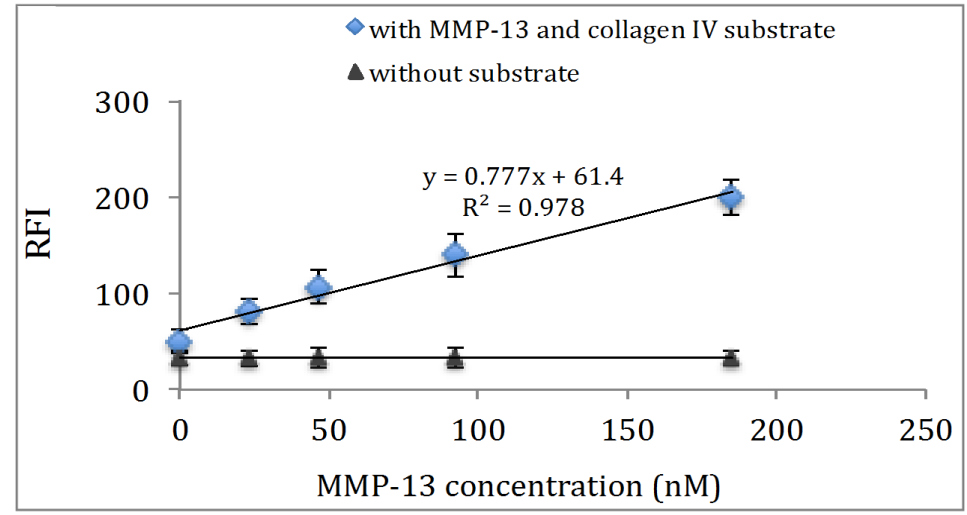

(b)

Figure 3. (a) Kinetics of the enzymatic degradation of $1.65 \mu \mathrm{M}$ collagen IV by 92.5 nM MMP-13; (b) Calibration curve of 0 - 185 nM MMP-13 using $1.65 \mu \mathrm{M}$ collagen IV. Error bars represent standard deviation in duplicate measurements.

human samples.

We then used a commercial human collagenase assay kit containing FITC-labeled bovine collagen I to test for collagenase activities in the same samples (Figure 4(b)). In this case, FITC-labeled large fragments were produced by the enzymatic reaction with human collagenase. After the reaction, the FL fragments were degraded by elastase, extracted from the unreacted FITC-labeled substrate, and measured by the spectrofluorometer. However, no collagenase activity was observed by this method. This FITC-labeled collagen method indicated a lower detection limit of 342 nM MMP-13 at S/N = 3. Furthermore, the FITC-labeled collagen substrate was unstable and decomposed during the 3-h enzymatic reaction.

Thus, our assay method using the substrate of human collagen IV for the assay of MMP-13 was approximately 4 times more sensitive than the FITC-labeled collagen method.

\subsection{Collagenase Activity Using Acetyl-Oligopeptide Substrate}

Human collagenase cleaves the collagen sequence-based oligopeptide GPQGIAGQ at the Gly-Ile site, producing $N$-terminal Ile-containing IAGQ peptide [12]. Here, we used Ac-GPQGIAGQ as substrate for an assay of human collagenase activity. IAGQ was selectively FL-labeled with a DHB reagent, as shown in Scheme 2. Previously [18], we evaluated the FL-labeling reactivity of DHB with $N$-terminal Phe-, Leu-, Ile-, Val- or Ala-containing oligopeptides. This reaction is performed at $100^{\circ} \mathrm{C}$ for $5 \mathrm{~min}$ in the presence of sodium borate (pH 7.5) and periodate.

Using this assay, the FL signals were proportional to the MMP-13 enzyme concentrations (9.25 - $148 \mathrm{nM})$, with $\mathrm{R}^{2}=0.999$, as shown in Figure 5(a). The lower detection limit of MMP-13 at S/N = 3 was 25 nM. This assay using acetyl-oligopeptide substrate was more sensitive and thus used to measure the enzyme activities in 


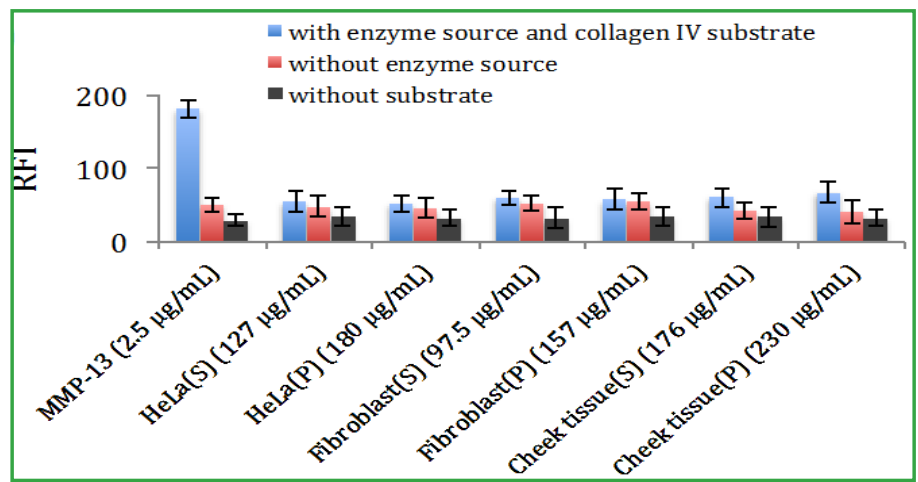

(a)

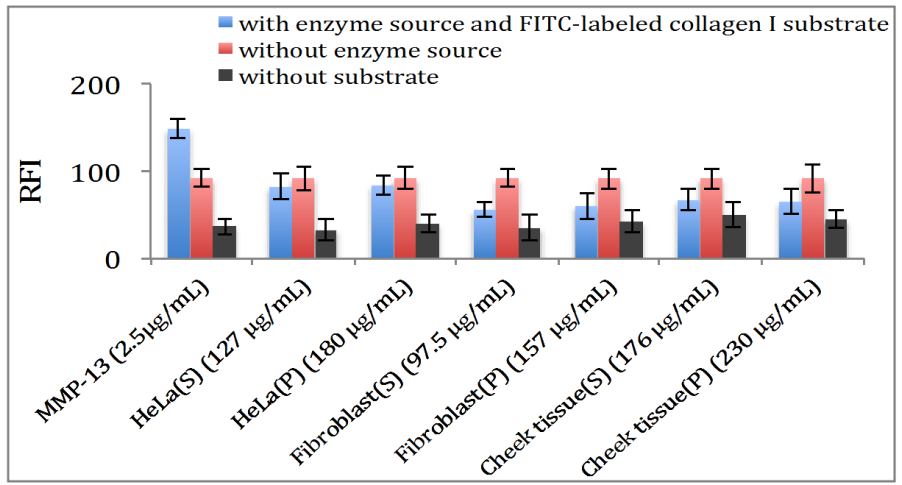

(b)

Figure 4. (a) Collagenase activities using $1.65 \mu \mathrm{M}$ collagen IV in cytosol (S) and cell debris (P) fractions of HeLa cells, fibroblast cells, and cheek tissue, as measured by the assay method discussed in the text; (b) Collagen activities in the same enzyme sources used for (a), measured with a FITC-labeled bovine collagen I substrate. The concentration of total proteins in each specimen is noted in parentheses. Error bars represent standard deviation in duplicate measurements.

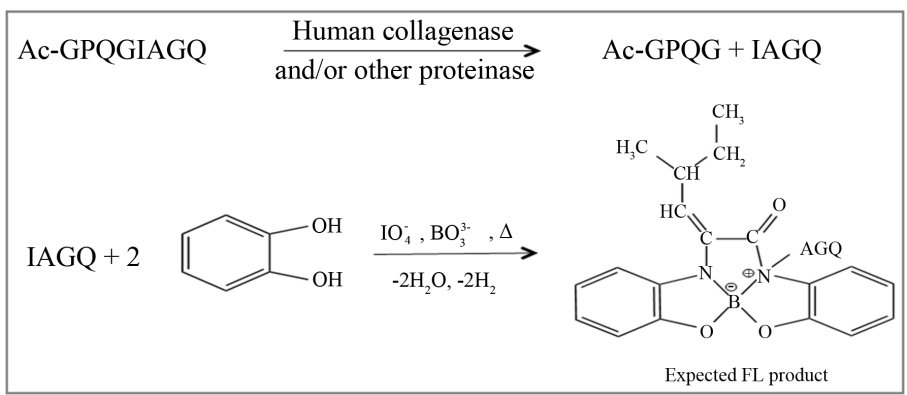

Scheme 2. Protocol for human collagenase assay using an acetyl-peptide substrate. The Ac-GPQGIAGQ substrate was hydrolyzed by human collagenase, producing IAGQ peptide that was selectively labeled with a DHB- based FL reaction.

the same biological sources discussed in Figure 4. As shown in Figure 5(b), intense activities were observed in cytosol fractions of cultured cells, in contrast with the negative results using collagen substrates (Figure 4).

\section{Conclusions}

A selective, sensitive, and convenient assay for human collagenase activity using native collagen or synthetic 


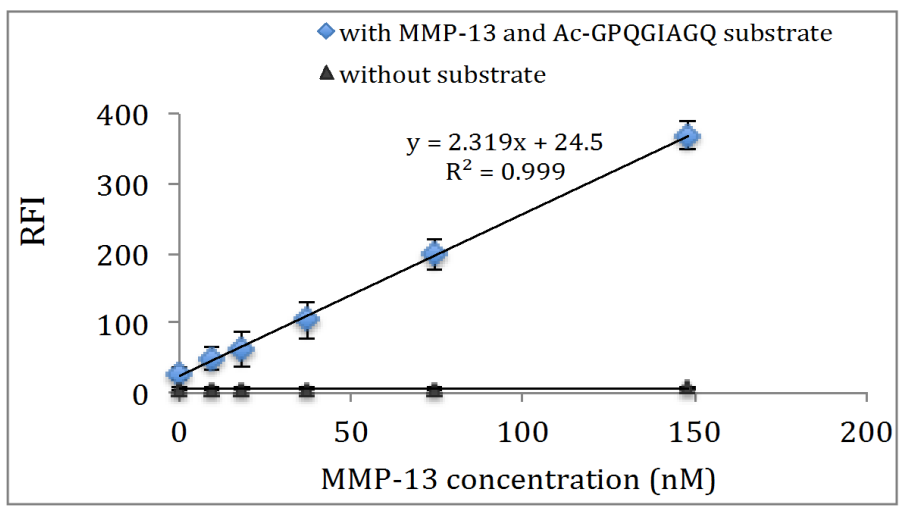

(a)

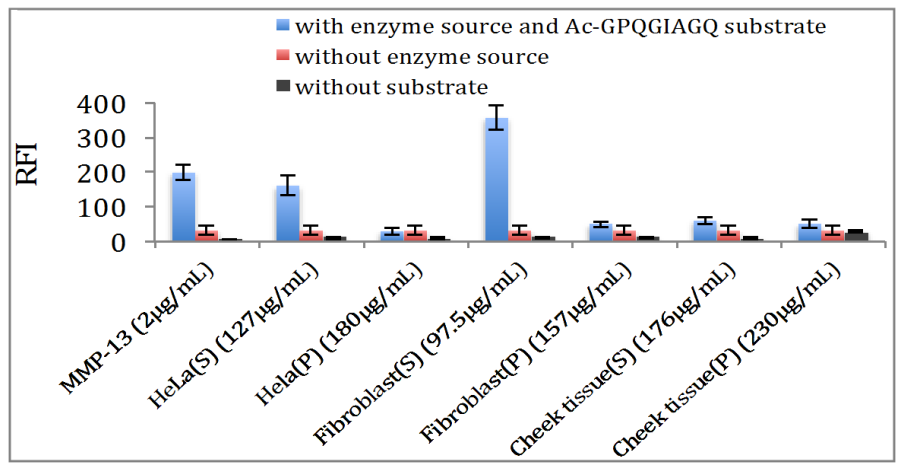

(b)

Figure 5. (a) Calibration of 0 - $148 \mathrm{nM}$ MMP-13 activities using 1.5 mM Ac-GPQGIAGQ substrate; (b) Collagenase activities in the cytosol (S) and cell debris (P) fractions of HeLa cells, fibroblast cells, and cheek tissue, as measured by the Ac-GPQGIAGQ substrate assay. The total protein concentration in each sample is given in parenthesis. Error bars represent standard deviation in duplicate measurements.

acetyl peptides was presented. The assay was based on selective fluorogenic labeling by either DHPAA or DHB reactions with peptide fragments cleaved from the substrate in the presence of borate and periodate. The collagenase assay conditions for MMP-13 enzyme activity were optimized and any label-free substrates can be used. Thus, various endogenous protease activities could be characterized by this assay.

When the assay was used to measure endogenous collagenase activity in crude biological specimens, such as human cultured cells and cheek tissue, their enzyme sources did not exhibit significant activities for either the collagen substrate (Figure 4(a)) or for commercial FITC-labeled bovine collagen I (Figure 4(b)). These results were probably explained by the low concentrations of collagenase in the samples; endogenous enzyme expression was generally very low and requires stimulation such as aging and/or UV light irradiation [30] [31]. In contrast, when the sequence-based acetyl-peptide substrate was used, intense collagenase activity was observed in the cytosol fractions of cultured cells (Figure 5(b)), which suggested the presence of other endogenous proteases or peptidases. Consequently, this assay would be useful for studies of collagen catabolism.

\section{Acknowledgements}

This work was supported by grants-in-aid for Scientific Research from the Ministry of Education, Culture, Sports, Science, and Technology of Japan and was partly supported by the Global Center of Excellence Program of Nagasaki University.

\section{References}

[1] Nagase, H. and Woesner Jr., J.F. (1999) Matrix Metalloproteinases. The Journal of Biological Chemistry, 274, 21491- 
21494. http://dx.doi.org/10.1074/jbc.274.31.21491

[2] Miller, E., Harris Jr., E.D., Chung, E., Finch Jr., J.E., McCroskery, P.A. and Butler, W.T. (1976) Cleavage of Type II and III Collagen with Mammalian Collagenase: Site of Cleavage and Primary Structure at the Amino-Terminal Portion of the Smaller Fragment Released from Both Collagens. Biochemistry, 15, 787-792. http://dx.doi.org/10.1021/bi00649a009

[3] Nagase, H., Barrett, A.J. and Woesner Jr., J.F. (1992) Nomenclature and Glossary of the Matrix Metalloproteinases. Matrix (Stuttgart, Germany). Supplement, 1, 421-424.

[4] Leeman, M.F., Curran, S. and Murray, G.I. (2002) The Structure, Regulation, and Function of Human Matrix Metalloproteinase-13. Critical Reviews in Biochemistry and Molecular Biology, 37, 149-166.

[5] Konttinen, Y.T., Salo, T., Hanemaaijer, R., Valleala, H., Sorsa, T., Sutinen, M., et al. (1999) Collagenase-3 (MMP-13) and Its Activators in Rheumatoid Arthritis: Localization in the Pannus-Hard Tissue Junction and Inhibition by Alendronate. Matrix Biology, 18, 401-412. http://dx.doi.org/10.1016/S0945-053X(99)00030-X

[6] Itoh, T., Uzaki, M., Shimamura, T. and Sawai, T. (2002) Dynamics of Matrix Metalloproteinase (MMP)-13 in the Patients with Rheumatoid Arthritis. Ryumachi [Rheumatism], 42, 60-69.

[7] Cawston, T.E. and Barret, A.J. (1979) A Rapid and Reproducible Assay for Collagenase Using $\left(1{ }^{14}\right.$ C)Acetylated Collagen. Analytical Biochemistry, 99, 340-345. http://dx.doi.org/10.1016/S0003-2697(79)80017-2

[8] Dean, D.D. and Woessner Jr., J.F. (1985) A Sensitive, Specific Assay of Tissue Collagenase Using Telopeptide-Free $\left({ }^{3}\right.$ H)Acetylated Collagen. Analytical Biochemistry, 148, 174-181. http://dx.doi.org/10.1016/0003-2697(85)90642-6

[9] Nagai, Y., Lapiere, C.M. and Gross, J. (1966) Tadpole Collagenase. Preparation and Purification. Biochemistry, 5, 31233130. http://dx.doi.org/10.1021/bi00874a007

[10] Karran, E.H., Dodgson, K., Harris, S.J., Markwell, R.E. and Harper, G.P. (1995) A Simple in Vivo Model of Collagen Degradation Using Collagen-Gelled Cotton Buds: The Effect of Collagenase Inhibitors and Other Agents. Inflammation Research, 44, 36-46. http://dx.doi.org/10.1007/BF01630486

[11] Knight, C.G., Willenbrock, F. and Murphy, G. (1992) A Novel Coumarin-Labelled Peptide for Sensitive Continuous Assay of Matrix Metalloproteinases. FEBS (Federation of European Biochemical Societies) Letters, 296, 263-266. http://dx.doi.org/10.1016/0014-5793(92)80300-6

[12] Clark, I.M., Wright, J.K. and Hazleman B.L. (1992) Polyclonal Antibodies against Human Fibroblast Collagenase and the Design of an Enzyme-Linked Immunosorbent Assay to Measure TIMP-Collagenase Complex. Matrix Biology, 12, 108115. http://dx.doi.org/10.1016/S0934-8832(11)80052-1

[13] Clark, I.M., Wright, J.K. and Hazleman, B.L. (1992) Monoclonal Antibodies against Human Collagenase and the Design of an Enzyme-Linked Immunosorbent Assay to Measure Total Collagenase. Matrix Biology, 12, 475-489. http://dx.doi.org/10.1016/S0934-8832(11)80092-2

[14] Plumpton, T.A., Clark, I.M., Plumton, C., Calvin, J. and Cawston, E. (1995) Development of an Enzyme-Linked Immunosorbent Assay to Measure Total TIMP-1 (Free TIMP-1 and TIMP-1 in Combination with Matrix-Metalloprotei- nases) and Measurement of TIMP 1 and CRP in Serum. Clinica Chimica Acta, 240, 137-154. http://dx.doi.org/10.1016/0009-8981(95)06137-7

[15] Kai, M. and Ohkura, Y. (1986) Selective Determination of $N$-Terminal Tyrosine Containing Peptides by a Novel Fluorescent Reaction with Borate, Hydroxylamine and Cobalt (II). Analytica Chimica Acta, 182, 177-183. http://dx.doi.org/10.1016/S0003-2670(00)82448-4

[16] Kojima, E., Ohba, Y., Kai, M. and Ohkura, Y. (1993) Phenylglioxal and Glyoxal as Fluorogenic Reagents Selective for $N$-Terminal Tryptophan-Containing Peptides. Analytica Chimica Acta, 280, 257-162. http://dx.doi.org/10.1016/0003-2670(93)80253-H

[17] Kabashima, T., Yu, Z.Q., Tang, C.H., Nakagawa, Y., Okumura, K., Shibata, T., et al. (2007) A Selective Fluorescence Reaction for Peptides and Chromatographic Analysis. Peptides, 29, 356-363. http://dx.doi.org/10.1016/j.peptides.2007.11.014

[18] Rahman, M.S., Kabashima, T., Yasmin, H., Shibata, T. and Kai, M. (2012) A Novel Fluorescence Reaction for $N$-Terminal Ser-Containing Peptides and Its Application to Assay Caspase Activity. Analytical Biochemistry, 430, $79-85$.

[19] Yasmin, H., Shibata, T., Rahman, M.S., Kabashima, T. and Kai, M. (2012) Selective and Sensitive Determination of Peptides Using 3,4-Dihydroxyphenylacetic Acid as a Fluorogenic Reagent. Analytica Chimica Acta, 721, $162-166$. http://dx.doi.org/10.1016/j.aca.2012.01.035

[20] Yasmin, H., Rahman, M.S., Shibata, T., Kabashima, T. and Kai, M. (2014) A Novel Fluorometric Method for the Selective Determination of Pro-Gly and Pro-Gly-Pro. International Journal of Peptide Research and Therapeutics, 30, 441-446. http://dx.doi.org/10.1007/s10989-014-9406-z

[21] Zhang, G.Q., Kai, M., Nakano, M. and Ohkura, Y. (1991) Pre-Column Fluorescence Derivatization High-Performance Liquid Chromatography of Opioid Peptides in Rat Brain and Its Use for Enzymatic Peptide Characterization. Chemical and Pharmaceutical Bulletin, 39, 126-129. http://dx.doi.org/10.1248/cpb.39.126 
[22] Kai, M., Kojima, E., Ohkura, Y. and Iwasaki, M. (1993) High-Performance Liquid Chromatography of N-Terminal Tryptophan-Containing Peptides with Precolumn Fluorescence Derivatization with Glyoxal. Journal of Chromatography A, 653, 235-240. http://dx.doi.org/10.1016/0021-9673(93)83179-V

[23] Yu, Z.Q., Kabashima, T., Tang, C.H., Shibata, T., Kitazato, K., Kobayashi, N., et al. (2010) Selective and Facile Assay of Human Immunodeficiency Virus Protease Activity by a Novel Fluorogenic Reaction. Analytical Biochemistry, 397, 197-201. http://dx.doi.org/10.1016/j.ab.2009.10.030

[24] Yasmin, H., Kabashima, T., Rahman, M.S., Shibata, T. and Kai, M. (2014) Amplified and Selective Assay of Collagen by Enzymatic and Fluorescent Reaction. Scientific Reports, 4. http://dx.doi.org/10.1038/srep04950

[25] Nagase, H. and Fields, G.B. (1996) Human Metalloproteinase Specificity Studies Using Collagen Sequence-Based Synthetic Peptides. Biopolymers (Peptide Sciences), 40, 399-416. http://dx.doi.org/10.1002/(SICI)1097-0282(1996)40:4<399::AID-BIP5>3.0.CO;2-R

[26] Sellers, A., Cartwright, E., Morphy, G. and Reynolds, J.J. (1977) Evidence That Latent Collagenases Are Enzyme-In- hibitor Complexes. Biochemical Journal, 163, 303-307.

[27] Gordon, M.K. and Hahn, R.A. (2012) Collagens. Cell and Tissue Research, 339, 247-257. http://dx.doi.org/10.1007/s00441-009-0844-4

[28] Han, S., Blumenfeld, O.O. and Seifter, S. (1992) Specific Identification of Collagens and Their Fragments by Clostridial Collagenase and Anti-Collagenase Antibody. Analytical Biochemistry, 201, 336-342. http://dx.doi.org/10.1016/0003-2697(92)90348-B

[29] Hu, Y., Webb, E., Singh, J., Morgan, B.A., Gainor, J.A., Gordon, T.D. and Siahaan, T.J. (2002) Rapid Determination of Substrate Specificity of Clostridium Histolyticum $\beta$-Collagenase Using an Immobilized Peptide Library. Journal of Biological Chemistry, 277, 8366-8371. http://dx.doi.org/10.1074/jbc.M111042200

[30] Forsyth, C.B., Cole, A., Murphy, G., Bienias, J.L., Im, H. and Loeser Jr., R.F. (2005) Increased Matrix Metalloproteinase13 Production with Aging by Human Articular Chondrocytes in Response to Catabolic Stimuli. Journal of Gerontology: Biological Sciences, 9, 1118-1124.

[31] Dong, K.K., Damaghi, N., Picart, S.D., Markova, N.G., Obayashi, K., Okano, Y., et al. (2008) UV-Induced DNA Damage Initiate Release of MMP-1 in Human Skin. Experimental Dermatology, 17, 1037-1044. http://dx.doi.org/10.1111/j.1600-0625.2008.00747.x 